\title{
Birthdays to Remember
}

\section{Citation}

Browne, Janet. 2008. Birthdays to remember. Nature 456: 324-325.

\section{Published Version}

http://dx.doi.org/10.1038/456324a

\section{Permanent link}

http://nrs.harvard.edu/urn-3:HUL.InstRepos:3372267

\section{Terms of Use}

This article was downloaded from Harvard University's DASH repository, and is made available under the terms and conditions applicable to Other Posted Material, as set forth at http:// nrs.harvard.edu/urn-3:HUL.InstRepos:dash.current.terms-of-use\#LAA

\section{Share Your Story}

The Harvard community has made this article openly available.

Please share how this access benefits you. Submit a story.

\section{Accessibility}




\section{Birthdays to remember}

\section{Anniversaries of Charles Darwin's life and work have been used to rewrite and re-energize his theory of natural selection. Janet Browne tracks a century of Darwinian celebrations.}

Anniversaries are big business in the cultural world and have long been convenient events for promoting agendas. Tourism, commerce, education; all these can be boosted in the name of an anniversary.

In science, anniversaries help us to explore the implications of truly important achievements, confirm shared ideas, highlight the value of key players and look forward to new problems to resolve. As we fast approach 2009, the bicentenary of Darwin's birth and the 150th year since the publication of On the Origin of Species, it is worth remembering that scientific anniversaries also provide an opportunity to push an agenda, and even to adapt the past, so telling us what we like best to hear.

It is becoming clear to historians that Darwin commemorations held at various points over the past century have been used to re-frame and re-establish the relevance of natural selection at delicate moments. Interest in Darwinism rose and declined noticeably after his death. The idea of natural selection fell out of favour around 1900, when the field of genetics came to life, and again in the 1950s when molecular biology emerged. Each of these new themes probably made existing biological explanations look old-fashioned. An increasing amount of evidence suggests that Darwinism needed intellectual reboots at strategic times in the twentieth century to become the theory that it is today. The urgency of these former scientific rallying points has been obscured by the success and high profile of modern selection theory.

\section{Funeral as propaganda}

The first such posthumous rallying event was Darwin's funeral in April 1882. This was an occasion for national glorification. As biographer James Moore described in a 1982 article $^{1}$, active scientific reformers in the Royal Society of London - including Thomas Henry Huxley, Francis Galton and John Lubbock moved rapidly after Darwin's death to obtain permission to bury him in Westminster Abbey, one of the most prominent religious buildings in Great Britain. This was a far cry from the simple funeral that Darwin had expected in his village church. Eight days later his coffin was carried with great ceremony through the nave of the abbey. The funeral service and many obituaries stressed that Darwin was not an atheist. He was instead described as a good man, committed to truth and honesty. This was true, but it was also valuable propaganda at a time when relations between science and religion were intensely fraught. The men of the Royal Society used Darwin's funeral as a way to reassure their contemporaries that science was not a threat to moral values, but rather was becoming increasingly important in the modern world.

In 1909, 100 years after Darwin's birth, a number of celebrations were held in Europe and North America. One of the more memorable took place at the University of Cambridge, UK, where two of Darwin's sons were professors. As documented by historian Marsha Richmond of Wayne State University in Detroit, Michigan $^{2}$, visiting scientists were given honorary degrees, Darwin's former college rooms in Christ's College were opened, manuscripts were displayed and a substantial volume of essays by noted biologists was published.

Less widely appreciated, however, is that this meeting took place at a time when Darwinism as a biological explanation was going through a bad patch. Some were beginning to think that the notion of gradual change simply wasn't needed. After the word 'genetics' was coined in 1905, much work focused on the mutation of chromosomes. It was assumed by great experimentalists such as Thomas Hunt Morgan and Theodosius Dobzhansky that the breaking and rejoining of chromosomes, or some other type of chromosome alteration, was sufficient to generate permanent change in an organism. Thus, new forms could emerge de novo, without selective pressure and adaptive success.

Darwinism had a troubled place in palaeontology, too. The subject was then leaping forwards with remarkable fossil discoveries, and it was increasingly possible to propose ancestral trees with some certainty. Yet it seemed as though fossil animals had progressed along particular lines of development, as if with some final purpose in mind - a notion that put teleology back into biology only 50 years after Darwin had done so much to try to remove it. At the same time, conventional evolutionary biology seemed to be losing any sense of unity, potentially diluting the power of Darwin's allembracing idea. Biometricians such as Karl Pearson focused on a statistical view of populations to study evolution; pioneering ecological thinkers such as Eugen Warming saw the key issue as organisms' struggle directly against the environment.

Darwinism as set out by Charles Darwin seemed increasingly sidelined. The 1909 commemorations, organized by a small group of naturalists and Darwin family members from the University of Cambridge, provided a way to reassert the primacy of natural selection against other evolutionary rivals.

\section{American stage}

Then, in 1959, a hundred years after On the Origin of Species was published, it was the turn of the United States and the new 'biological systematics', argues historian Betty Smocovitis of the University of Florida in Gainsville ${ }^{3}$.

This Darwin anniversary was held at the University of Chicago in Illinois, in a symposium that pointedly celebrated the integration of genetics and population statistics with selection theory. Ten years earlier, this integration had almost taken the form of a political treaty. Putting it bluntly, field naturalists were eager to
re-establish their value in an
"Darwin would surely be amazed by how differently we have chosen to celebrate his anniversaries." increasingly laboratory-based world. Prominent naturalists such as Ernst Mayr managed to get geneticists and statisticians to agree that evolution could take place on three levels: in molecules; in the flow of genes through populations; and in the environmental world of organisms undergoing competition and natural selection. In 1942, Julian Huxley invented the phrase 'modern synthesis' to combine genetics with natural selection, and Mayr's key work within this synthesis, Systematics and the Origin of Species from the Viewpoint of a Zoologist (Columbia Univ. Press), was published.

The delegates at Chicago did more than celebrate a new union of the biological sciences. They in effect created modern Darwinism by emphatically rejecting any form of Lamarckism - the doctrine that an organism could pass on traits acquired through environmental conditions during its lifetime. In 1959, socialist Russia had only recently withdrawn 


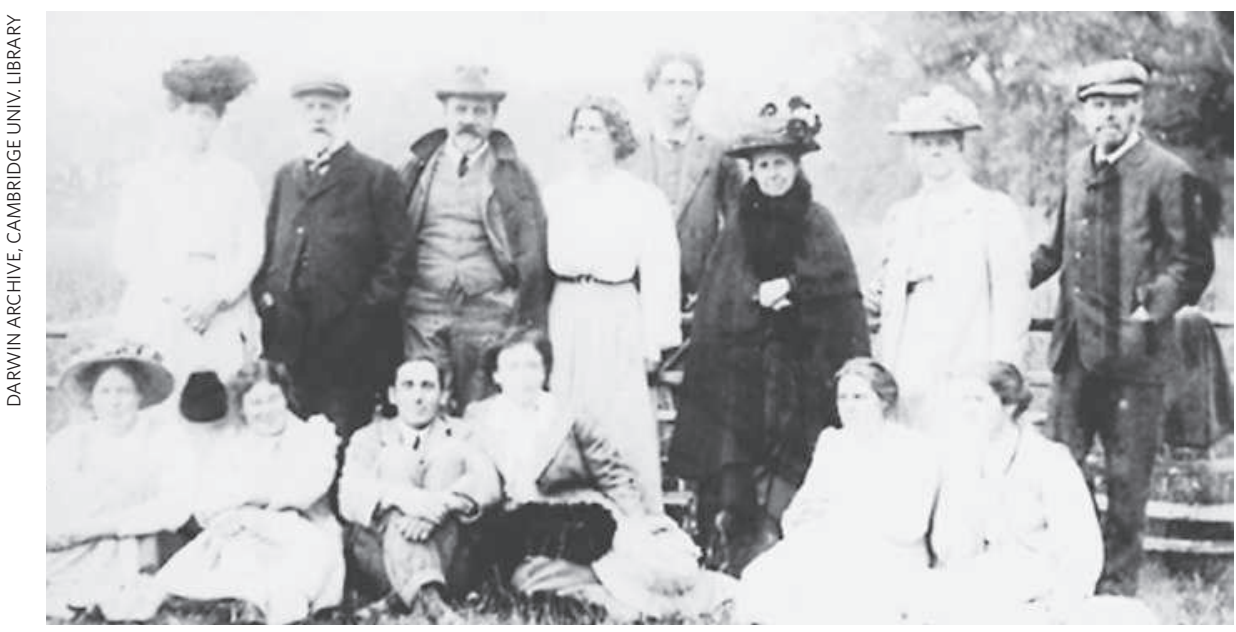

Party snaps: Darwin family members gathered at the 1909 celebrations in Cambridge, UK (above); Darwin's grandson, the physicist Charles Galton Darwin (below left) on a 1959 televised US talk show with colleague Julian Huxley (centre) and politician Adlai Stevenson (right).

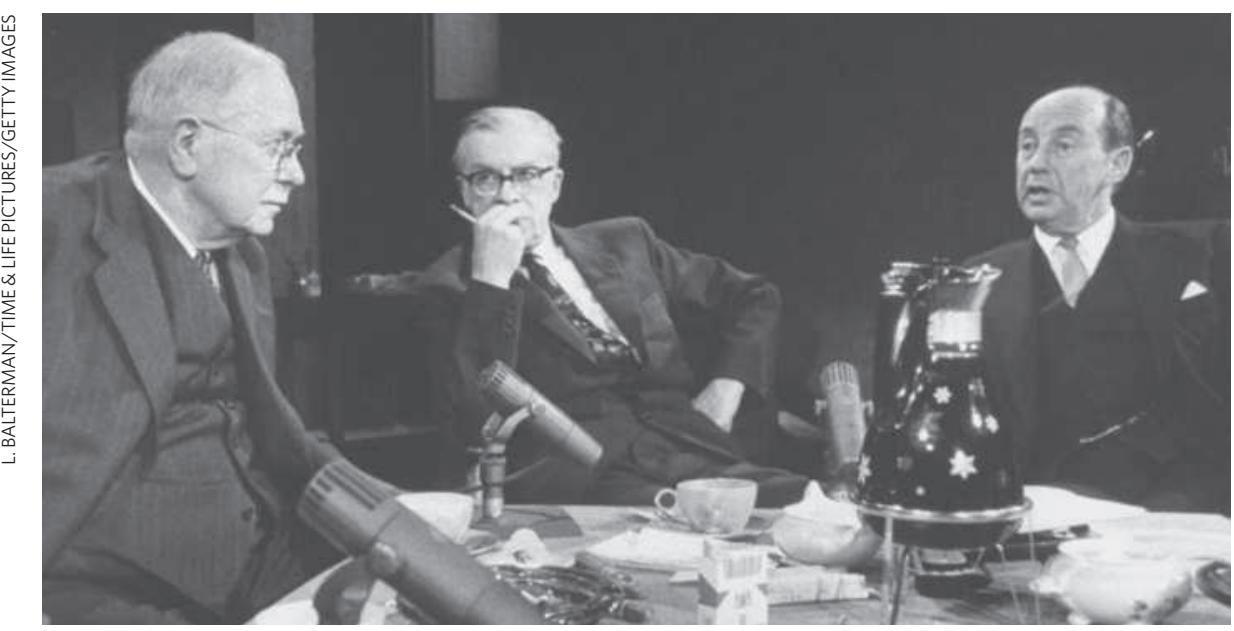

from Lamarckism in genetics, and the idea was strongly associated in US minds with the cold-war struggle. The delegates also rejected the idea that the fossil record shows signs of directed evolution, and expanded Darwinian thought to cover the evolution of mind and behaviour. During the conference, Julian Huxley, the grandson of Thomas Henry Huxley, gave a secular sermon in the style of his grandfather, and provocatively declared that religious belief was merely a biological feature of evolving mankind.

\section{Evolution of a theory}

The story of Darwin's finches as a classic example of evolution in action also became more widely known at this point. Biologist David Lack had been encouraged by Mayr and Julian Huxley to spend time studying the finches on the Galapagos archipelago, first with a view to their ecology, but then as an example of beak diversification according to the availability of foodstuffs and lack of other bird competition. It was only after this, according to Frank Sulloway of the University of California, Berkeley, that the finches sketched by Darwin became collectively known as Darwin's finches, and were held up as the first and most remarkable evidence of evolution in real organisms in a natural setting.

In fact, much of what we know about Darwin and Darwinism, including his celebrity status, is the result of the 1959 celebration in Chicago. Plans were announced for a Darwin memorial park on the Galapagos Islands, which tied in with international pressure on Ecuador to restrict commercial fisheries and allowed the islands to become a designated World Heritage area. Darwin's original books and papers were preserved through munificent bequests from US foundations and the Darwin family, and several noteworthy biographies were published.

In 2009 we shall see an unprecedented number of Darwin commemorations, including scientific symposia, books (see page 323), postage stamps and a big-budget film (see page 322 ).
Will these forthcoming activities have a veiled agenda, as did those of the past?

Without question, biologists will pay tribute to the theory itself - a magnificent achievement that lives on as the central organizing concept of modern biology and much else besides. In 1859, the clarity and insight of Darwin's vision in On the Origin of Species provided real answers to the biggest naturalhistory problems of his day. Since then, the idea of evolution by natural selection has been restructured from the bottom up, to account for new fields such as genetics. In this way it has persisted, and shown remarkable explanatory power for nearly 150 years.

But biologists will also surely use the occasion, once again, to affirm the truth and elegance of Darwinism in the face of criticism, this time from those who prefer a creationist view of the world. Evolution by natural selection has suddenly become a highly contentious idea, especially in the United States. Creationist proponents abound in the US school-board system, opinion polls highlight the public's belief in a divine origin for humankind, and ideas about intelligent design are widely circulated. Against this, Darwin has become the figurehead for rational, secular science, and Darwinism the main target of the fundamentalist movement spreading across the globe. Attacks extend beyond arguments over the Bible. To criticize Darwinism is a forceful way to express anxieties about the growing power of modern science and the perceived decline of moral values in society. To try to poke holes in Darwin's argument is to express dislike not just for evolutionary theory but also for science itself.

There is some irony in this situation. Looking back to Darwin's funeral in 1882, Darwin's Christian qualities, his stature as a man of truth and honesty, were brought to the fore. He was celebrated as a man whose religious doubts were an integral part of his wisdom and insight; few critics made personal attacks on his social virtues. Now, his heroism in modern science is seen by many as an offence to religious values. It goes to show just how diversely Darwin and his theory have been perceived and used over the years. Darwin himself would surely be amazed by how differently we have chosen to celebrate his anniversaries.

Janet Browne is a historian of the life sciences at Harvard University, and the author of books including Darwin's Origin of Species: A Biography. e-mail: jbrowne@fas.harvard.edu

\footnotetext{
1. Moore, J. R. Biol. J. Linn. Soc. Lond. 17, 97-113 (1982)

2. Richmond, M. L. Isis 97, 447-484 (2006).

3. Smocovitis, V. B. Osiris Second Series 14, 1-66 (1999).
}

See also pages 281, 295, 322 and 323, and online at www.nature.com/darwin. 